\title{
Experiment on Sand Incubator: An Alternative Mini-Hatchery Technique for Smallholder Poultry Farmers
}

\author{
Yonatan Kassu Netsanet Beyero \\ Department of Animal and Range Science, Wolaita Sodo University \\ P. O. Box 138, Wolaita Sodo, Ethiopia
}

\begin{abstract}
The experiment was conducted to compare and evaluate the hatchability and survival rate of a sand incubator and natural hen incubation technique and to estimate the profitability of the two different incubation techniques. The results of this study indicated that fertility, hatchability and dead in shell there were no significant difference $(\mathrm{P}>0.05)$ among the treatments. Embryonic mortality, normal DOC, abnormal DOC and chick weight showed significant differences $(\mathrm{P}<0.05)$ among the treatments. Higher embryonic mortality $(17 \%)$ in broody hen than $(9.2 \%)$ in sand incubator was observed. On the first batch, the net return per 100 eggs in sand incubation was 177.83 ETB (\$9.3) which is higher net return/ profit from that of the broody hen incubation (-441.05 ETB) or (\$23.0 ) which were not profitable for the first batch at $70.80 \%$ hatchability. On the 1 st year run the net return was estimated and can incurred by sand incubator which make it sustainable in profitability for the smallholder farmers by making high income for the next seven years of production period. Finally in order to improve the performance of the hatchery traits before the technology adopt to the farmers intensive adoptive research should be conduct and also training of smallholder poultry producers in the hatchery management of sand incubator is very crucial.
\end{abstract}

Keywords: Sand incubator, broody hen, hatchability, net return

\section{Introduction}

Poultry production is an area of animal agriculture, where human food production is relatively fast, initial capital investment is low and use can be made of available household labour. In a developing country like Ethiopia, poultry production in rural areas is of great importance as a prime supplier of eggs and meat and as a source of income, especially to women (Solomon, 1996).) Indigenous poultry contribute almost 99\% of the national egg and poultry meat production (Tadelle et al., 2003). However due to the low productivity (poor egg production performance, slow growth rate, late sexual maturity) and broodiness for an extended period limit the advantage obtain from this sector. Past attempts that have been made in the country to improve the production and productivity of local birds through upgrading (distribution of exotic birds) and cross breeding (Tadelle and Peters, 2003). The exotic breeds generally do have high productivity in terms of eggs and meat production performance. However the limit for these breeds is that they did not hatch and produce day old chicken by their own due to lack of broadness and farmers forced to use the local broody hens, which are not enough to meet the actual demand of farmers and producers who want to carry out small-scale operations. A broody hen can hardly hatch 10 eggs in good management practice (Roy et al., 2004).

The much known techniques to hatch improved chicken breed eggs is using modern electric incubator. Modern electric incubators are equipped with automatic devices and generally used by the commercial hatcheries for hatching chicken eggs to meet the huge demand for quality chicks all over the world particularly in the developed countries. This context is not applied in a rural part of many developing country where there is no or/ intermittent electric supply and the price of modern incubator not easily afforded by the rural community and small-scale operation enterprises.

Mini-hatcheries can be constructed from cheap materials available locally, such as rice husk, quilts and sand, to retain heat. The incubators can be easily made using readily available skills and tools. Sand-based minihatcheries give the highest hatching percentages for both chicken and duck eggs (80-85 and 70-72\% respectively, compared with $70-75 \%$ and $65-68 \%$ for rice husk incubators and $75-80 \%$ and $60-62 \%$ for rice husk and quilt incubators (Rota et al., 2011).

Mini-hatcheries are an incubator which is made from locally available materials to incubate chicken or duck eggs. Min-hatchery incubators have been used to hatch chicken and duck eggs in Egypt and China and Bangladesh. However, the system was not widely adopted by most of developing countries (Hassan, 2011). Surprisingly little is known about the efficiency of mini-hatchery like sand incubation and rice husk incubation.

In Ethiopia improved chicken breed which have been distributed through packages to farmers for the purpose of improving the production status of local chicken and also to generate income by selling their products but the farmers do not have any kind of mini hatchery technology that could be hatch a number of chicks other than use of local chicken to hatch egg, because the improved chicken do not incubate and hatch their egg due to low maternity instinct and broodiness. Despite increasing demand for meat, egg, and qualities chicks, the minihatchery operation in the country is not well known and organized. Therefore, it has become necessary to find a 
method of egg incubation that is less risky and less expensive which are affordable and be adopted equally by all sections of urban and rural people through better utilization of existing resources in the country. Therefore, the current study is aimed to evaluate and estimate the suitability, performance and profitability of the sand incubator technique by comparing with the local broody hen hatching technique.

\section{Material and Methods}

Precinct of study site

The experiment was conducted in Wolaita Sodo University. The University is located in the mid highlands of southern Ethiopia at $330 \mathrm{~km}$ south of Addis Ababa at about $6049^{\prime} \mathrm{N}$ latitude and 370 45' E longitudes and the farm is situated altitude of 1710 meter above sea level (m.a.s.l). The average mean maximum and minimum temperature are $26.80 \mathrm{C}$ and $11.40 \mathrm{C}$, respectively and the mean maximum and minimum relative humidity is $91.4 \%$ and $39.92 \%$ respectively. The mean annual rainfall of the area is $1212 \mathrm{~mm}$ (NMSA, 2011).

\section{Experimental Animal and materials}

\section{Hatching eggs}

A total of 747 fertile eggs from the breeds of White leghorn were purchased from Hawassa poultry breeding and distribution center. The hatching eggs were selected for medium and uniform in size with average weight of $54 \pm$ $1.6 \mathrm{~g}$ which also have strong shell. The eggs were stored in a room at $14^{\circ} \mathrm{C}$ to $16^{\circ} \mathrm{C}$ and $70-80 \%$ relative humidity for 4 days. Before setting, all eggs were properly clean with mild luke-warm water solution of savlon (a mild disinfectant). Shape index of hatch able eggs were measured.

\section{Selection and collection of broody hens}

Twenty-one broody hens with the same age and body size $(852 \pm 31 \mathrm{~g})$ were purchased from local market. The broody hens were divided randomly into three replications each replication had 7 broody hens for incubation of seven hatching eggs. Before incubation, all broody hens were treated to remove both internal and external parasites. A complete layer grower ration containing $12.9 \mathrm{MJ} / \mathrm{kg}$ and $16.4 \% \mathrm{CP}$, and fresh drinking water was provided as adli-tum.

\section{Sand incubation techniques}

A sand incubator was modified and produced wood workshop which was constructed with materials such as wood, metal plates, jute sacks, black garment, cotton, and sand. Before and after setting the eggs, the incubator was as thoroughly fumigated by using potassium permanganate and formaldehyde as per recommendations. The eggs were sat in the setting trays of the incubator with the small end down and the large end up at the optimum conditions of temperature $\left(37-39^{\circ} \mathrm{C}\right)$, relative humidity $(60 \%)$ and frequent ventilation were maintained during the whole period of incubation using the topside opening and sometimes front door opening. Turning of eggs was done by rolling with a clean hand with gentle circular motion 6 times in 24 hours at 4 hours interval up to 18 days of incubation period. In both treatments, the candling of eggs was done by using torch-light on the $7^{\text {th }}$ and $14^{\text {th }}$ day of incubation. All clear and early dead embryos were removed after each candling.

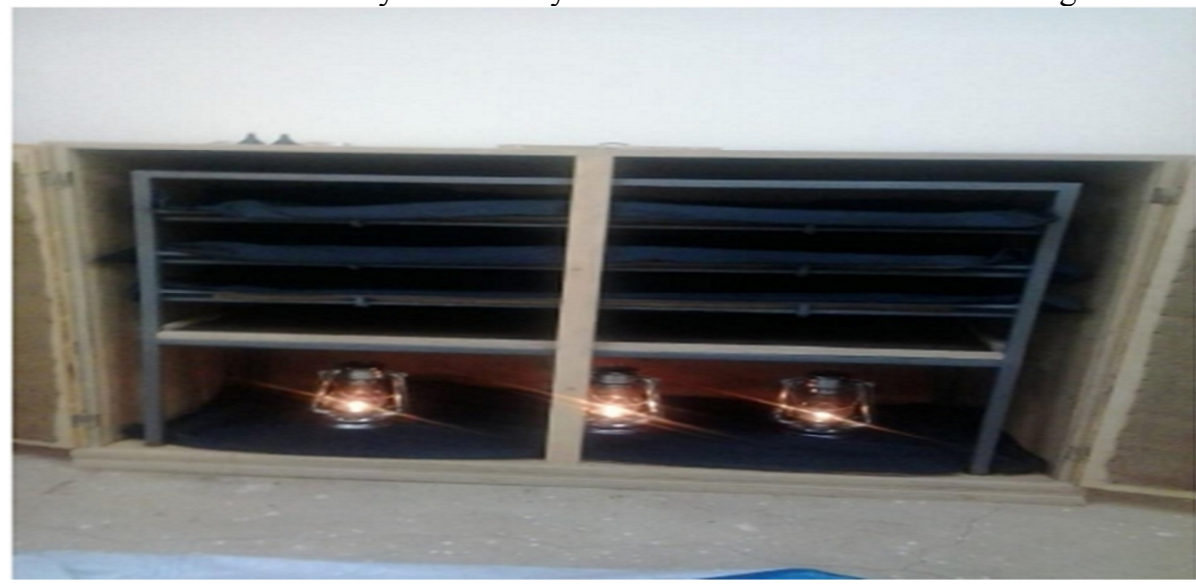

Figure 1. Sand incubator preparation

Data collection

Data were collected for fertility, embryonic mortality, dead-in-shells, abnormal chicks hatched, normal chicks hatched, day-old chick weight, survival of day-old chick, hatchability were considered in both methods of incubation techniques. All hatched chicks were weighed individually on a treatment basis with by using sensitive balance with $0.5 \mathrm{~g}$ accuracy.

Statistical analysis

All the data collected were subjected to statistical analysis of variance using the PROC GLM of statistically Analysis software SAS 9.2 version (SAS Institute Inc, 2008). For the means those had a significant different, 
Least Significant Difference (LSD) procedure was used. Total estimation of cost and return for each incubation techniques budget analysis was made for each incubation techniques.

\section{Results and Discussion}

\section{Hatchability trait performance}

Number of egg set per batch, percentage of embryonic mortality, dead in shell, hatchability, normal/ abnormal day old chick (DOC), chick weight and survival rate are shown in table 1. The number of egg set for sand incubator and broody hen is different due to the different holding capacity of eggs for broody hen and sand incubator.

Table 1. Hatchability traits of eggs incubated under different methods of incubation

\begin{tabular}{|l|l|l|l|l|l|}
\hline & & \multicolumn{2}{l|}{ Method of incubation } & \\
\cline { 3 - 6 } S.no & Hatchability traits & Broody hen & Sand incubation & P value & Sig. \\
\hline 1 & No. of egg set per batch & 147 & 600 & & \\
\hline 2 & Fertile egg\% & $85.8 \pm 0.6227$ & $87.3 \pm 1.453$ & 0.406 & NS \\
\hline 3 & Embryonic mortality $\%$ & $17.0 \pm 1.2282$ & $9.1566 \pm 1.4183$ & 0.014 & $*$ \\
\hline 4 & Hatchability from total eggs \% & $60.43 \pm 1.1259$ & $54.17 \pm 5.8902$ & 0.355 & NS \\
\hline 5 & Hatchability from fertile egg\% & $70.80 \pm 1.08$ & $61.8 \pm 6.1941$ & 0.205 & NS \\
\hline 6 & Dead in shell\% & $12.20 \pm 1.5716$ & $29.033 \pm 5.9839$ & 0.052 & NS \\
\hline 7 & Normal DOC\% & $91.53 \pm 1.3667$ & $96.833 \pm 0.2603$ & 0.019 & $*$ \\
\hline 8 & Abnormal DOC\% & $8.47 \pm 1.3667$ & $3.1667 \pm 0.2603$ & 0.019 & $*$ \\
\hline 9 & Chick weight $(g)$ & $35.20 \pm 0.4932$ & $37.1933 \pm 0.4233$ & 0.037 & $*$ \\
\hline 10 & Survival rate $\%$ & $50.77 \pm 7.2549$ & $98.140 \pm 0.9567$ & 0.003 & $* *$ \\
\hline
\end{tabular}

Values indicate mean $\pm S E$; values within rows without superscript in common differ at $P<0.05$ Legends: * and ** significant differences at $5 \%(p<0.05)$ and $1 \%(p<0.01)$ level of significant, respectively; NS= Nonsignificant.

The hatchability of fertile eggs had no significant different $(\mathrm{P}>0.05)$ between the two incubation techniques. But numerically higher hatchability percentage was recorded from broody hen $(70.8 \%)$ than the sand incubation (61.8\%). Dolberg et al., (2002); Sonaiya, and Swan, (2004) reported that the hatching rates of the mini-hatchery technique were in the range 50 to $70 \%$ which is similar to the current finding $(62 \%)$ which is very satisfactory, considering that in most of the mini-hatcheries operated with sand and kerosene fuel. In spite of the satisfactory hatchability rate from sand incubator the hatchability rate declines we goes up from the source of heat distributor (sand tray) to the top $\left(2^{\text {nd }}\right.$ and $\left.3^{\text {rd }}\right)$ tray. This is due to ununiformed heat distribution through the incubator box which was at arrange of $36.5-39{ }^{0} \mathrm{C}$ from top tray to the bottom respectively.
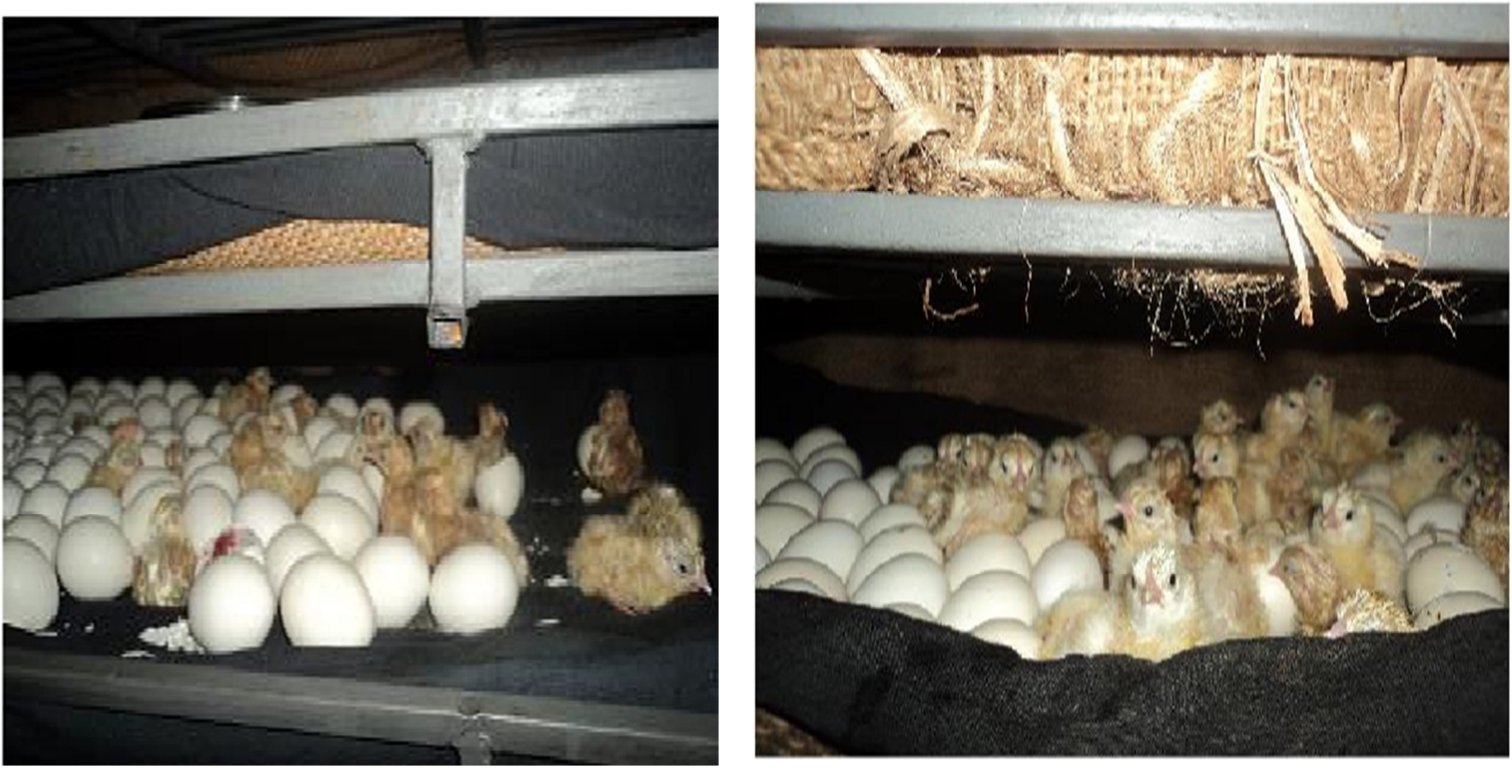

Figure 2. Chicks that hatched on sand incubator

The embryonic mortality of broody hen is significantly $(\mathrm{P}<0.05)$ higher than that of the sand incubator. Embryonic mortality caused by inadequate ventilation, heat, humidity and vice versa (Dafwang et al., 2005). Broody hen leaves their nest to search for feed and water at this time it might be a fluctuation in temperature which lead to embryo mortality especially after the $13^{\text {th }}$ day of incubation when the embryonic development become faster. Even if the percentage of the dead in shell of broody hen incubation $(12 \%)$ and sand incubation 
technique $(29 \%)$ was not significantly different $(\mathrm{P}>0.05)$, the sand incubation technique had numerically higher percentage of dead-in-shell. However in our case to maintain humidity in sand incubator was very difficult due to lack of appropriate hatchery room and provinces humidity condition may cause a severe increase in the proportion of embryo dead-in-shell. Broody hens are experienced enough to maintain optimum conditions of temperature and humidity. Roy et al (2004) reported that dead-in-shell and embryonic mortality rates in the broody hen $2 \%$ and $4.80 \%$ respectively. El-Ayadi (1956) reported that White Leghorn eggs dead-in-shell rates were $20.0 \%$

As shown in table 1 that, the percentage of normal and abnormal day old chicks hatch had a significant difference $(\mathrm{P}<0.05)$ among the two incubation techniques. Abnormal chicks are produced could be due to poor management of the parent flock, environmental conditions in the hatchery room and some genetical/breed factors may contribute for the abnormal chicks.

The implication from the findings of the present study is that the methods of incubation had significant effect on abnormal chicks hatched. The treatments also had influence on normal chicks hatched. Number of sound chicks is an indication of success of hatchability.Day old chicks weight found to be significantly higher than broody hen incubation technique $(\mathrm{P}<0.05)$. This difference might be due to inadequate supplementation of heat during the incubation period which result poor/retarded embryonic growth/development. The current study result is disagree with Roy et al (2004) which indicate that the average chick weight for broody hen incubation and rice husk incubation were $27 \mathrm{~g}$ which is lower than the current study; this could be the difference in chick strain most of the time the higher breed do have high chick weight whereas lower chicken breed do have lower chick weight.

The survival rate of the hatched chick for one week for broody hen incubation technique $(50.7 \%)$ was significantly lower $(\mathrm{p}<0.01)$ than sand incubation technique $(98.1 \%)$ as shown in table 1 . Among the indigenous local fowls, percentage of the chicks hatched died before they reached cockerel or pullet stage and annually percentage of the entire flock die before the keeper could reap any benefits in terms of meat or eggs. The difference in survival rate between the two incubation techniques were due to the difference in the management practice. The sand incubated chicks were kept in hover which they were supplemented by kerosene lamp shown a better survival rate whereas the broody hen are the only source of heat for the chicks.

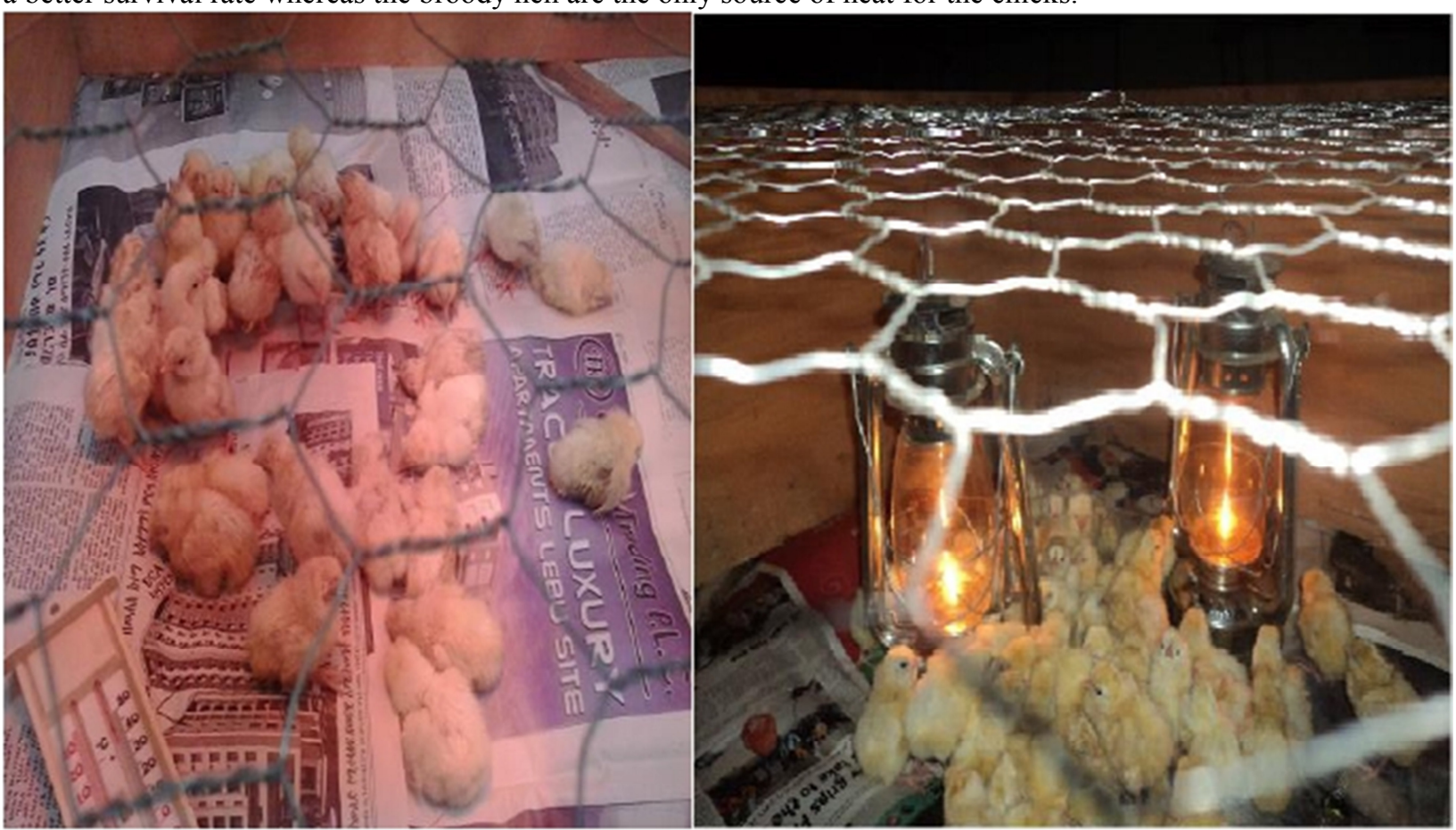

Figure 3. DOC after transformed in to their solomon brooder cage run

\section{Cost and Return of the incubation techniques}

The costs and returns of the two different incubation techniques are shown in Table 2 and table 3 . The total fixed cost per batch for sand incubation was 5255 ETB (\$273.7); which is about $72.60 \%$ of the gross cost and from which $66.60 \%$ of the fixed cost was spent for the production of the incubator.

From the study the cost of production using broody hen was very less than that of sand incubation technique. The broody hen technique cost makes $94.5 \%$ and $50.3 \%$ of the total fixed cost and gross cost respectively. Natural incubation technique is attribute of the broody hen no further heating material are required 
rather than straw because the hen itself provide all the heat required by the egg in order to develop and hatch.

Table 2. The fixed and variable costs for hatcheries in two different incubation techniques

\begin{tabular}{|c|c|c|c|c|c|}
\hline \multicolumn{3}{|c|}{ Sand incubator } & \multicolumn{3}{|c|}{ Broody hen } \\
\hline \multirow[b]{2}{*}{ Fixed cost } & \multicolumn{2}{|c|}{ Price } & \multirow[b]{2}{*}{ Fixed cost } & \multicolumn{2}{|c|}{ Price } \\
\hline & ETB & USD & & ETB & USD \\
\hline Sand incubator & 3500.0 & 182.3 & Hen & 1470.0 & 76.60 \\
\hline Lamp & 225.00 & 11.70 & House rent & 50.00 & 2.60 \\
\hline Jute sacks & 90.00 & 4.70 & Torch & 35.00 & 1.80 \\
\hline Cloth & 225.00 & 11.70 & & & \\
\hline Thermometer & 180.00 & 9.40 & & & \\
\hline Hygrometer & 950.00 & 49.50 & & & \\
\hline House rent & 50.00 & 2.60 & & & \\
\hline Torch (candling) & 35.00 & 1.80 & & & \\
\hline Total fixed cost & $\mathbf{5 2 5 5 . 0}$ & 273.7 & & 1555.0 & 81.0 \\
\hline \multicolumn{2}{|c|}{ Sand incubator } & & \multicolumn{2}{|c|}{ Broody hen } & \\
\hline Variable cost & Price (ETB) & $\begin{array}{l}\text { Price } \\
\text { USD } \\
\end{array}$ & Variable cost & ETB & USD \\
\hline Egg & 1200.0 & 62.50 & Egg & 294.00 & 15.30 \\
\hline Kerosene & 118.00 & 6.10 & Feed & 461.60 & 24.00 \\
\hline Disinfectant & 140.00 & 7.30 & Medicine & 90.00 & 4.70 \\
\hline Labor & 525.00 & 27.30 & Labor & 525.00 & 27.3 \\
\hline Total variable total & 1983.0 & 103.3 & Total variable cost & 1370.6 & 71.4 \\
\hline
\end{tabular}

$1 U S D=19.20$ ETB by the time of the study

The total variable cost of sand incubation was higher than the broody hen incubation method this is due to the difference in capacity and material difference in the two incubation techniques. Although kerosene lamp were used as a source of heat supplementation for sand incubator in order to hatch a chick and after they transferred in to brooder house up to $2^{\text {nd }}$ weeks of their age which replace the hen function in natural incubation technique. In this experiment the gross return derived from the return of day-old-chick sale and unfertile egg sale. The gross return per batch attributed by sand incubator was four times higher than the natural incubation technique (table 3). A well designed sand incubator with $800 \mathrm{egg}$ capacity can be used /serve as up to eight year with 10 successful batch per year. Whereas a single hen only incubate an egg for two subsequent production years and can incubate, hatch and brood a chick three times per year.

In the first batch of incubation, which was including all fixed costs, the gross return per 100 eggs in sand incubation method was greater return from that of the broody hen incubation. While the net return per 100 eggs in sand incubation was177.83 ETB (\$9.3) which is higher return from that of the broody hen incubation (441.05 ETB) or (\$-23.0) which were not profitable for the first batch at $70.80 \%$ hatchability. After the $1^{\text {st }}$ batch of incubation the net returns were increasing and sustained in both of incubation techniques this is due to the production costs not account the fixed costs. On the $1^{\text {st }}$ year run the net return was estimated and can incurred by sand incubator which make it sustainable in profitability for the smallholder farmers by making high income for the next seven years of production period. However the hatchability of the sand incubator can be increase through time with improvement in managing before and after the egg incubation process/operation and on the availability of quality /fertile eggs which domino effect boosts the profitability the smallholder farmers through this technology.

Table 3.Total cost, gross returns and net return for each production year

\begin{tabular}{|c|c|c|c|c|c|c|c|c|c|c|c|c|}
\hline \multirow{4}{*}{ Cost items } & \multicolumn{4}{|c|}{ per batches } & \multicolumn{4}{|c|}{ Per first year run } & \multicolumn{4}{|c|}{ per $2^{\text {nd }}$ year run } \\
\hline & \multirow{2}{*}{\multicolumn{2}{|c|}{$\begin{array}{c}\text { Sand incubator } \\
\text { Price } \\
\end{array}$}} & \multirow{2}{*}{\multicolumn{2}{|c|}{\begin{tabular}{|c|} 
Broody hen \\
Price
\end{tabular}}} & \multirow{2}{*}{\multicolumn{2}{|c|}{$\begin{array}{c}\text { Sand incubator } \\
\text { Price } \\
\end{array}$}} & \multicolumn{2}{|c|}{ Broody hen } & \multirow{2}{*}{\multicolumn{2}{|c|}{$\begin{array}{c}\text { Sand incubator } \\
\text { Price } \\
\end{array}$}} & \multirow{2}{*}{\multicolumn{2}{|c|}{\begin{tabular}{|r|} 
Broody hen \\
Price \\
\end{tabular}}} \\
\hline & & & & & & & & & & & & \\
\hline & ETB & USD & ETB & USD & ETB & USD & ETB & USD & ETB & USD & ETB & USD (\$) \\
\hline Depreciation cost $10 \%$ & 0 & 0 & - & & - & - & - & & 550.00 & 28.65 & - & - \\
\hline Total variable cost & 1983.00 & 103.3 & 1370.60 & 71.4 & 19830.00 & 1032.8 & 4111.80 & 214.2 & 19830.00 & 1032.8 & 4111.80 & 214.2 \\
\hline Total fixed cost & 5255.00 & 273.7 & 1555.00 & 81.0 & - & - & - & - & - & - & - & - \\
\hline Gross costs & 7238.00 & 377.00 & 2925.60 & 152.4 & 27068.00 & 1409.8 & 7037.40 & 366.5 & 20380.00 & 1061.5 & 4111.80 & 214.2 \\
\hline Gross costs/100eggs & 1206.40 & 62.8 & 1986.40 & 103.5 & 4511.60 & 235.0 & 4778.27 & 248.9 & 3396.88 & 176.9 & 2791.87 & 145.4 \\
\hline Gross return & 8305.00 & 432.6 & 2277.25 & 118.6 & 91175.0 & 4748.7 & 9056.75 & 471.7 & 83050.0 & 4325.5 & 6831.75 & 355.8 \\
\hline Gross return/100 eggs & 1384.17 & 72.1 & 1549.15 & 80.7 & 15195.83 & 791.4 & 6161.05 & 320.9 & 13050.00 & 679.7 & 4647.45 & 242.1 \\
\hline Net return & 1067 & 55.6 & -684.35 & -35.6 & 64107.00 & 3338.9 & 2019.35 & 105.2 & 62670.00 & 3264.1 & 2719.95 & 141.7 \\
\hline Net return/100 eggs & 177.83 & 9.3 & -441.05 & -23.0 & 10684.50 & 556.5 & 1373.71 & 71.5 & 10445 & 544.0 & 1850.31 & 96.4 \\
\hline
\end{tabular}

\section{Conclusion}

Hatchability percentage were lower in sand incubation method than that of the natural incubation however it is operated with kerosene fuel. Although the sand incubation techniques from the point of number and cost of the 
incubator it could hatch a number of chicks per batch (600 eggs) and profitability was higher than that of broody hen incubation technique. In the first year run period earning $\$ 3,339$ amount money will be a significant addition to the income of the smallholder farmers.

Therefore intensive adoptive research should be conduct in different agro climatic condition and seasons and training should be given to smallholder poultry producers on the hatchery management of sand incubator before the technology adopt to the farmers is very crucial and also to make it incentive for the farmers and to explore the profitability of the sand incubator techniques there is need to better DOC (day old Chick) price, low cost of hatching egg, technical support, built-in linkages between producers of fertile eggs and the mini-hatcheries, and from the mini-hatcheries to DOCs rears are also necessary to assist farmers to improve their productivity, and thus increasing households' income.

\section{References}

Solomon D. (1996). Study on the egg production of White Leghorn under intensive, semi-intensive and rural household conditions in Ethiopia. Livest. Res. Rural Dev. 8: 89-92.

Tadelle, D, Million T, Alemu, Y, Peters, K.J. (2003). Village chicken production systems in Ethiopia: Use pattern and performance valuation and chicken products and socio economic functions of chicken. Livest. Res. Rural Dev. 15:1-4.

Tadelle D, Peters K. J. (2003). Indigenous chicken in Ethiopia: their genetic potential, attempts made in the past for improvement and future areas of research, Animal Breeding for Tropics and sub-tropics press.

Roy B. C, Ranvig H, Chowdhury S D, Rashid M M, Faruque M R. (2004). Production of day-old chicks from crossbred chicken eggs by broody hens, rice husk incubator and electric incubator, and their rearing up to 6 weeks. Livest. Res. Rural Dev. 16 (Suppl 3):1-8.

Rota A, Brett N, Nahar J, Rahman S M R, Ali Y, Sarwar A, Fattah K. A. (2011). Building and operating a minihatchery: Sand method. International Fund for Agricultural Development (IFAD) press.

Hassan J. (2011). Mini-hatchery: a low cost hatching technology. [Abstract] Network for the Veterinarians of Bangladesh, 1:2. Database. http://bdvets.org/

NMSA (2011). (National Metrological Service Agency): monthly report, Addis Ababa, Ethiopia.

SAS Institute Inc (2008). Statistical analysis Software version 9.2, Cary, NC: SAS Institute Inc. USA.

Dolberg, F. Mallorie, E. Brett, N. (2002). Evolution of poultry model- a pathway out of poverty. In proceeding of People Fight with Poultry. Learning from Bangladesh Experience: 20-24 October 2002; Dhaka, 2002:18-21. Database. http://ifad.org/english/operations/pi/bgd/documents/poultry.pdf

Sonaiya, E.B. and Swan S. (2004). Manual on Small-Scale Poultry Production. FAO Animal Production and Health series. http://fao.org/docrep/008/y5169e/y5169e00.htm\#Contents

Dafwang I I, Odiba J.Y, Ikani E.I. (2005). Hatchery management practices in poultry. National agricultural extension and research liaison services Ahmadu Bello University, Zaria. Extension bulletin 86: S 5.

El-Ayadi M.N. (1956). Fertility and hatchability as related to quality in Baladi commercial eggs. Poultr Scienc, $41(2): 1707-1712$. 
The IISTE is a pioneer in the Open-Access hosting service and academic event management. The aim of the firm is Accelerating Global Knowledge Sharing.

More information about the firm can be found on the homepage:

http://www.iiste.org

\section{CALL FOR JOURNAL PAPERS}

There are more than 30 peer-reviewed academic journals hosted under the hosting platform.

Prospective authors of journals can find the submission instruction on the following page: http://www.iiste.org/journals/ All the journals articles are available online to the readers all over the world without financial, legal, or technical barriers other than those inseparable from gaining access to the internet itself. Paper version of the journals is also available upon request of readers and authors.

\section{MORE RESOURCES}

Book publication information: http://www.iiste.org/book/

Academic conference: http://www.iiste.org/conference/upcoming-conferences-call-for-paper/

\section{IISTE Knowledge Sharing Partners}

EBSCO, Index Copernicus, Ulrich's Periodicals Directory, JournalTOCS, PKP Open Archives Harvester, Bielefeld Academic Search Engine, Elektronische Zeitschriftenbibliothek EZB, Open J-Gate, OCLC WorldCat, Universe Digtial Library, NewJour, Google Scholar

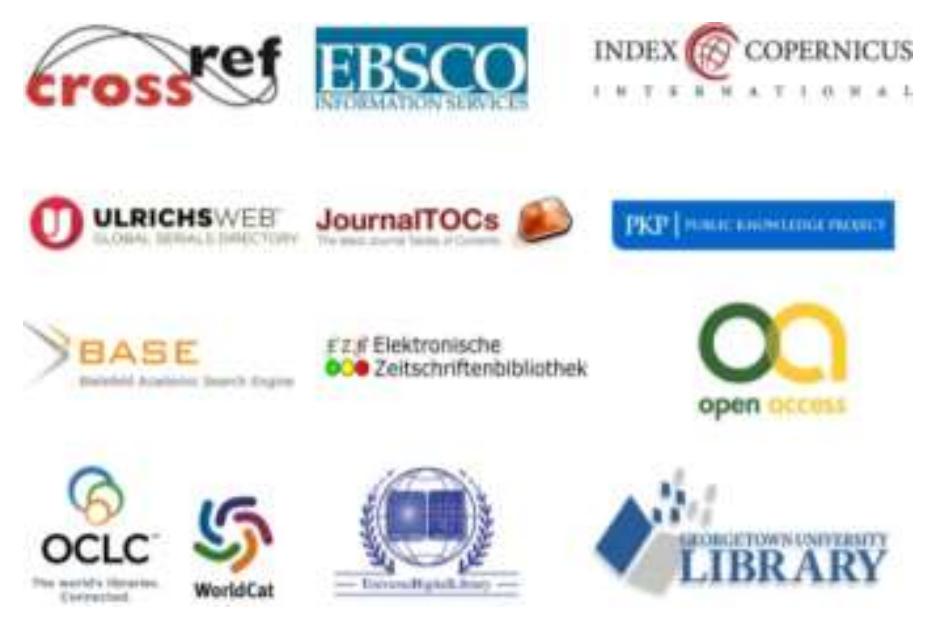

